\title{
$\begin{array}{ll}\text { Research Square } & \text { Preprints are preliminary reports that have not undergone peer review. } \\ \text { They should not be considered conclusive, used to inform clinical practice, }\end{array}$
}

\section{Proteinuria May Be an Indicator of Adverse Pregnancy Outcomes in Patients With Preeclampsia: A Retrospective Study}

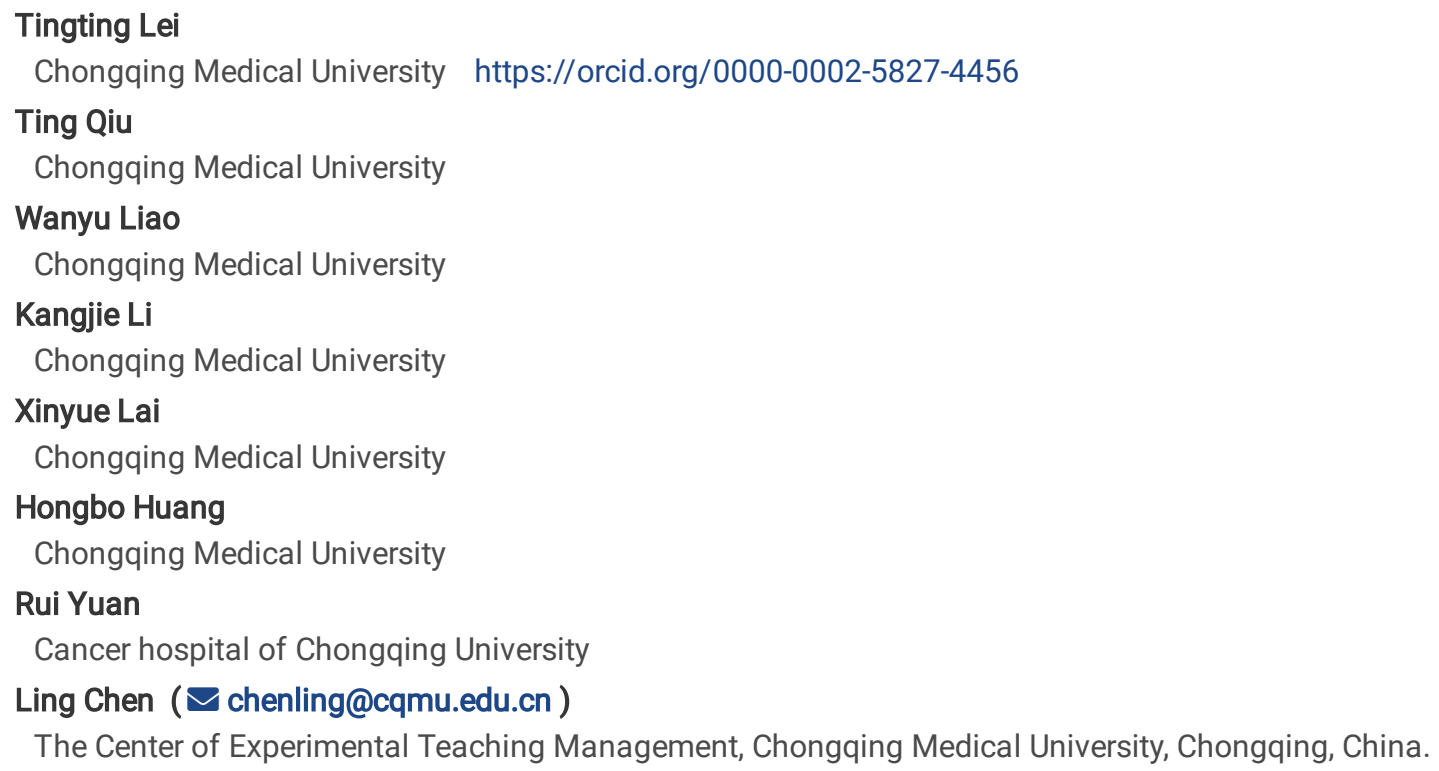

\section{Research Article}

Keywords: Preeclampsia, Proteinuria, Pregnancy complications, Neonatal outcome, Gestational hypertension

Posted Date: February 16th, 2021

DOI: https://doi.org/10.21203/rs.3.rs-230643/v1

License: (1) This work is licensed under a Creative Commons Attribution 4.0 International License. Read Full License 


\section{Abstract}

Background: Proteinuria is one of the common manifestations of patients with preeclampsia(PE), but whether the severity of proteinuria is related to the pregnancy outcome of patients with preeclampsia remains controversial. The present study aimed to determine the relationship between 24-hour proteinuria and adverse outcomes in patients with preeclampsia.

Methods: Retrospectively reviewed the clinical records of 329 pregnant women in Chongqing City. Patients were divided into PE group and non-PE group. PE group was divided into three subgroups according to the level of 24-hour proteinuria. Correlation analysis was used to analyze the correlation between biochemical indexes and adverse pregnancy outcome, and Logistic regression analysis was used to analyze the risk factors of adverse pregnancy outcome. The receiver operating characteristic curve (ROC) was used to evaluate the ability of 24-hour urinary protein to distinguish the adverse pregnancy outcome in patients with preeclampsia.

Results: (1) Among mild (proteinuria $<0.3 \mathrm{~g} / 24 \mathrm{~h})$, moderate $(0.3 \mathrm{~g} / 24 \mathrm{~h} \leqq$ proteinuria $<2 \mathrm{~g} / 24 \mathrm{~h}$ ) and massive (proteinuria $\geqq 2 \mathrm{~g} / 24 \mathrm{~h}) \mathrm{groups}$, the frequencies of induced labor $(p=0.006)$, hypoproteinemia $(p<0.001)$ and stillbirth $(p=0.002)$ increased according to the severity of 24 hour proteinuria. Patients with a proteinuria $>2 \mathrm{~g} / 24 \mathrm{~h}$ had a shorter gestational week $(p<0.001)$ and a higher preterm delivery rate $(p=$ 0.009). (2) Adverse pregnant outcome was positively correlated with 24-hour proteinuria (adverse maternal outcomes: $r=0.239, p=0.002$; adverse fetal outcomes: $r=0.336, p<0.001$ ). (3) The best 24 -hour proteinuria cutoff value to determine adverse outcomes was 872.09 $\mathrm{mg} / 24 \mathrm{~h}(p<0.001)$, odds ratios ( $95 \%$ confidence interval, $\mathrm{Cl}$ ) was $5.03(2.60-9.74)$. For hypoproteinemia, the best value was $1935 \mathrm{mg} / 24 \mathrm{~h}$ $(p<0.001)$ and ORs $(95 \% \mathrm{Cls})$ was 6.7(2.6-17.4). For stillbirth, premature and intrauterine distress the best value were $3965.0 \mathrm{mg} / 24 \mathrm{~h}$, $984.75 \mathrm{mg} / 24 \mathrm{~h}$ and $1503.85 \mathrm{mg} / 24 \mathrm{~h}$ and ORs (95\% Cls) were 12.46 (3.46-44.88), 2.48 (1.15-5.37) and 10.02 (2.14-46.80), respectively.

Conclusions: The severity of 24-hour proteinuia may forecast adverse outcomes in women with preeclampsia. We suggest proteinuria should be retained as a prognostic indicator for patients with preeclampsia.

Trial registration: retrospectively registered.

\section{Background}

Preeclampsia (PE), a kind of placental disease, is the most representative type of hypertensive disorder complicating pregnancy. The incidence of preeclampsia accounts for $3 \%-8 \%$ of all pregnancies, seriously affecting the health of mothers and infants [1]. Pregnant women with preeclampsia are prone to organ system dysfunction, leading to various adverse pregnancy outcomes, such as retinopathy, impaired renal function, preterm delivery, fetal growth restriction (FGR), etc. But the risk factors of adverse pregnancy outcomes need to be further explored $[2,3,4]$. A number of studies have shown that patients with preeclampsia should be wary of the occurrence of adverse pregnancy outcomes when large amounts of proteinuria occur $[1,3,5]$. In the past, China recognized detection of 24-hour urine protein test as the "gold standard" in the diagnosis of preeclampsia [6]. However, in recent years, many studies concluded that the degree of proteinuria had nothing to do with the severity of preeclampsia, and there was no definite relationship between proteinuria and pregnancy outcomes in patients with preeclampsia $[7,8]$. It can be seen that the role of urinary protein in diagnosis and assessment of preeclampsia is still controversial. In this study, we retrospectively analyzed the relationship between 24-hour proteinuria and adverse pregnancy outcomes in patients with preeclampsia, and explored whether the level of urinary protein affects the adverse pregnancy outcome in order to provide research evidence for clinical diagnosis and treatment of preeclampsia.

\section{Methods}

\section{Data Sources}

In present study, We retrospectively reviewed the clinical records of 329 pregnant women during January 2015 to July 2020 in Chongqing area. There were 275 pregnant women diagnosed as preeclampsia and the other 54 pregnant women without preeclampsia were examined by obstetrics in the same period.

\section{Grouping}

We divided 329 pregnant women into PE group (pregnant women with preeclampsia, $n=275$ ) and non-PE group (pregnant women without preeclampsia, $\mathrm{n}=54$ ).

\section{PE group}

Loading [MathJax]/jax/output/CommonHTML/jax.js 


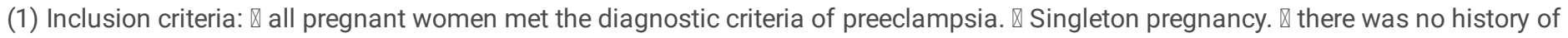
essential hypertension, nephropathy and diabetes. $\otimes$ the information was complete, including the detection of urinary protein.

(2) Exclusion criteria: $₫$ multiple pregnancies. $\otimes$ patients with essential hypertension, nephropathy and diabetes mellitus. $\otimes$ no delivery record due to spontaneous discharge or loss of follow-up. $\otimes$ patients with incomplete laboratory and auxiliary examination data.

(3) Diagnostic criteria of preeclampsia: the diagnostic criteria of preeclampsia refer to the diagnostic criteria of PE established in the guidelines for diagnosis and treatment of hypertensive disorder complicating pregnancy (2015 Edition).

(4) Based on the amount of proteinuria (tested by the detection of 24-hour urinary protein), the PE group was divided into three subgroups: A: mild group, 24-hour urinary protein < 0.3g; B: moderate group, 24-hour urinary protein $0.3 \sim 2 \mathrm{~g}$; C: massive group ,24-hour urinary protein $\geqq$ $2 \mathrm{~g}$.

\section{Non-PE group}

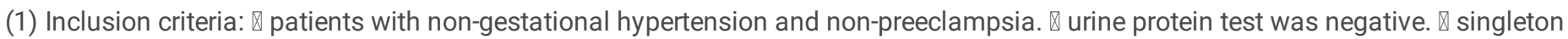
pregnancy. 区the information was complete, including the detection of urinary protein.

(2) Exclusion criteria: $\varangle$ multiple pregnancies. $\otimes$ patients with essential hypertension, nephropathy and diabetes mellitus. $\otimes$ those who have no delivery record due to spontaneous discharge or loss of follow-up. $\otimes$ the data of laboratory and auxiliary inspection are incomplete.

\section{Design}

Retrospectively reviewed the clinical records of pregnant women at the time of admission and delivery, including age, first delivery or not, gestational weeks, mode of delivery, systolic blood pressure (SBP), diastolic blood pressure (DBP), past medical history, laboratory indicators, maternal outcomes, fetal outcomes and other information. $\otimes$ The laboratory indexes include alanine aminotransferase (ALT), aspartate aminotransferase (AST), serum albumin, uric acid and creatinine. $\otimes$ Adverse pregnancy outcomes included retinal disease, hypoproteinemia, organ dysfunction (abnormal liver function, cardiac dysfunction, renal dysfunction, pleural and peritoneal effusion), placental abruption, oligohydramnios, eclampsia, maternal death, hemorrhagic anemia, postpartum hemorrhage, disseminated intravascular coagulation (DIC). $\otimes$ Adverse fetal outcomes include: premature delivery, fetal growth restriction (FGR), fetal distress, low birth weight, neonatal asphyxia, stillbirth, macrosomia, neonatal hypoxic encephalopathy, fetal malformation. In order to explore whether urinary protein is a risk factor for adverse pregnancy outcome in patients with $\mathrm{PE}$, we analyze the differences of various indexes and pregnancy outcomes between PE group, non-PE group and PE subgroup.

\section{Statistical Analyses}

The statistical analyses were performed using the statistical software SPSS24.0. Counting variables were expressed by frequency and analyzed by chi-square test; continuous variables were expressed by Xbar $\pm \mathrm{s}$ and analyzed by $T$-test. Correlation analysis was used to analyze the correlation between biochemical indexes and adverse pregnancy outcome, and Logistic regression analysis was used to analyze the risk factors of adverse pregnancy outcome. The receiver operating characteristic curve (ROC) was used to evaluate the ability of 24-hour urinary protein to distinguish the adverse pregnancy outcome in patients with preeclampsia. The difference was statistically significant $(P<0.05)$.

\section{Results}

\section{Characteristics of Included Patients}

Table 1 shows clinical characteristics of the 329 pregnant women. Among patients with PE, 170 patients measured 24-hour proteinuria, and divided them into 3 groups according to the quantitative level of 24 hour urine protein (A vs. B vs. C). Group A was defined as proteinuria < $0.3 \mathrm{~g} / 24$ hours $(\mathrm{n}=53$, mean 24-hour proteinuria $=136.27 \pm 89.39 \mathrm{mg} / 24 \mathrm{~h}$ ), group $B$ was defined as 0.3 to $2 \mathrm{~g} / 24$ hours ( $\mathrm{n}=64$, mean 24 -hour proteinuria $=884.29 \pm 538.33 \mathrm{mg} / 24 \mathrm{~h}$ ) and group $\mathrm{C}$ was defined as urinary protein excretion exceeding $2 \mathrm{~g}$ in 24 hours ( $\mathrm{n}=53$, mean 24 -hour proteinuria $=6246.13 \pm 5099.54 \mathrm{mg} / 24 \mathrm{~h})$.

Between non-PE and PE groups, the maternal age and cesarean section rate were higher in PE group than non-PE group $(p<0.001)$. Laboratory findings such as SBP and DBP at admission, ALT, AST, uric acid and creatinine level in PE group were higher than those in nonPE group $(p<0.001)$, the levels of albumin was lower than those in non-PE group $(P<0.001)$.

Loading [MathJax]/jax/output/CommonHTML/jax.js 
Among three subgroups, $\mathrm{C}$ group had a shorter gestational age at delivery than $\mathrm{A}$ and $\mathrm{B}$ group $(p<0.001)$. Laboratory findings such as SBP, DBP, uric acid and creatinine were found higher in C group than A and B group $(p<0.001)$. We also found that the higher level of proteinuria was, the lower level of albumin $(p<0.001)$. The other clinical characteristics such as age, nulliparaty, mode of delivery were not significantly different among three groups.

\section{Table1:Characteristics of included women}

\begin{tabular}{|c|c|c|c|c|c|c|c|}
\hline & \multirow[t]{2}{*}{ Non-PE } & \multirow[t]{2}{*}{ PE } & \multirow{2}{*}{$\begin{array}{l}p \\
\text { value }\end{array}$} & \multicolumn{3}{|l|}{ Subgroups } & \multirow{2}{*}{$\begin{array}{l}p \\
\text { value }\end{array}$} \\
\hline & & & & A & B & $\mathrm{C}$ & \\
\hline number & 54 & 275 & - & 53 & 64 & 53 & - \\
\hline \multicolumn{8}{|l|}{$\begin{array}{l}\text { Clinical } \\
\text { characteristics }\end{array}$} \\
\hline Mean age & $27.61 \pm 4.52$ & $30.16 \pm 5.53$ & $<0.001$ & $31.70 \pm 5.51$ & $30.27 \pm 6.00$ & $31.28 \pm 5.12$ & 0.180 \\
\hline Gestation week & $37.96 \pm 3.71$ & $36.65 \pm 3.68$ & 0.012 & $37.19 \pm 2.20$ & $37.31 \pm 2.87$ & $34.53 \pm 4.19^{\mathrm{ab}}$ & $<0.001$ \\
\hline \multicolumn{8}{|l|}{ Mode of delivery } \\
\hline Spontaneously & 38 & 24 & $<0.001$ & 6 & 1 & 1 & 0.038 \\
\hline Caesarean section & 14 & 232 & & 46 & 59 & 42 & \\
\hline \multicolumn{8}{|l|}{$\begin{array}{l}\text { Laboratory } \\
\text { findings }\end{array}$} \\
\hline $\mathrm{SBP}, \mathrm{mmHg}$ & $113.46 \pm 9.67$ & $146.34 \pm 18.24$ & $<0.001$ & $140.76 \pm 14.23$ & $143.67 \pm 17.72$ & $155.40 \pm 19.53^{\mathrm{ab}}$ & $<0.001$ \\
\hline $\mathrm{DBP}, \mathrm{mmHg}$ & $70.5 \pm 8.53$ & $95.44 \pm 13.68$ & $<0.001$ & $91.30 \pm 9.83$ & $93.60 \pm 13.10$ & $104.15 \pm 14.42^{\mathrm{ab}}$ & $<0.001$ \\
\hline ALT, U/L & $14.58 \pm 13.34$ & $34.59 \pm 64.46$ & $<0.001$ & $37.79 \pm 93.46$ & $24.51 \pm 25.83$ & $43.62 \pm 78.85$ & 0.055 \\
\hline AST, U/L & $18.37 \pm 6.89$ & $35.82 \pm 49.85$ & $<0.001$ & $35.70 \pm 67.53$ & $30.01 \pm 40.16$ & $43.63 \pm 64.72$ & 0.191 \\
\hline Albumin,g/L & $37.44 \pm 4.55$ & $34.15 \pm 4.92$ & $<0.001$ & $36.63 \pm 3.62$ & $34.23 \pm 4.38^{\mathrm{a}}$ & $31.38 \pm 4.52^{\mathrm{ab}}$ & $<0.001$ \\
\hline Uric acid, $\mu \mathrm{mol} / \mathrm{L}$ & $315.72 \pm 67.35$ & $424.38 \pm 108.67$ & $<0.001$ & $352.09 \pm 82.85$ & $419.66 \pm 119.40^{a}$ & $460.14 \pm 99.80^{a}$ & $<0.001$ \\
\hline Creatinine, $\mu \mathrm{mol} / \mathrm{L}$ & $45.22 \pm 6.23$ & $62.53 \pm 46.85$ & $<0.001$ & $46.44 \pm 8.46$ & $58.53 \pm 18.95$ & $72.52 \pm 41.09^{a b}$ & $<0.001$ \\
\hline $\begin{array}{l}\text { 24-hour urine } \\
\text { collection, } \mathrm{mg} / 24 \mathrm{~h}\end{array}$ & - & - & - & $136.27 \pm 89.39$ & $884.29 \pm 538.33$ & $6246.13 \pm 5099.54^{\mathrm{ab}}$ & $<0.001$ \\
\hline
\end{tabular}

ALT, Alanine aminotransferase; AST, Aspartate aminotransferase; DBP, Diastolic Blood Pressure; SBP: Systolic Blood Pressure; A: 24-hour urinary protein $<0.3 \mathrm{~g} ; \mathrm{B}: 24$-hour urinary protein $0.3 \sim 2 \mathrm{~g} ; \mathrm{C}: 24$-hour urinary protein $\geqq 2 \mathrm{~g}$; a compared with $\mathrm{A}$ group $\rrbracket p<0.05 ; \mathrm{b}$ compared with $\mathrm{B}$ group, $p<0.05$.

\section{Comparison of Adverse Pregnancy Outcomes In Pregnant Women}

Table 2 shows the adverse pregnancy outcomes. The frequencies of adverse outcomes (both maternal and fetal complications included) were $27.78 \%$ in non-PE group and $51.27 \%$ in PE group $(p=0.001)$. For patients with different proteinuria level, the frequency of adverse pregnancy outcomes was $41.5 \%$ in group A, $45.3 \%$ in group B and $77.4 \%$ in group $C(p<0.001)$, it seems that the higher degree of proteinuria, the higher chance of adverse outcomes.

The number of maternal complications in PE group (92/275, 33.5\%) was more than that in non-PE group $(2 / 54,3.7 \%),(P<0.001)$. Compared with non-PE group, PE group had a higher incidence in hypoproteinemia $(p=0.006)$, organ dysfunction $(p=0.041)$, retinal detachment $(p=0.047)$. Other maternal outcomes such as pleural and peritoneal effusion, eclampsia, DIC, postpartum hemorrhage, hemorrhagic anemia, placental abruption, maternal death, has no significant difference compared with normal pregnancy group $(p>0.05)$. 
In PE subgroups, The induction rate was different among 3 groups $(p=0.006)$. The incidences of hypoproteinemia, organ dysfunction were significantly different among three groups(A: 5.7\%; B: $12.5 \%$; C: 35.8\%; $p<0.001$ for hypoproteinemia; A: $5.7 \%$; B: $0 \%$; C: $13.2 \% ; p=0.010$ for organ dysfunction). No significant differences were observed in other maternal complications, such as placental abruption, retinal detachment. No pregnant women died in the three groups.

\section{Table2:Comparison of maternal complications}

\begin{tabular}{|c|c|c|c|c|c|c|c|}
\hline & \multirow[t]{2}{*}{ Non-PE } & \multirow[t]{2}{*}{ PE } & \multirow[t]{2}{*}{$p$ value } & \multicolumn{3}{|c|}{ subgroups } & \multirow[t]{2}{*}{$p$ value } \\
\hline & & & & $A$ & B & $\mathrm{C}$ & \\
\hline number & 54 & 275 & & 53 & 64 & 53 & \\
\hline \multicolumn{8}{|l|}{ Mode of delivery } \\
\hline Spontaneously & 38 & 24 & $<0.001$ & 6 & 1 & 1 & 0.038 \\
\hline Caesarean section & 14 & 232 & & 46 & 59 & 42 & \\
\hline Induction & 2 & 19 & 0.378 & 1 & 4 & 10 & 0.006 \\
\hline $\begin{array}{l}\text { Total adverse } \\
\text { outcomes }\end{array}$ & 15 & 145 & 0.001 & 22 & 29 & 41 & $<0.001$ \\
\hline adverse maternal outcomes & 2 & 92 & $<0.001$ & 11 & 21 & 26 & 0.009 \\
\hline Retinal disease & 0 & 19 & 0.047 & 1 & 2 & 3 & 0.561 \\
\hline Hypoproteinemia & 1 & 44 & 0.006 & 3 & 8 & 19 & $<0.001$ \\
\hline Organ dysfunction & 0 & 20 & 0.041 & 3 & 0 & 7 & 0.010 \\
\hline Maternal death & 0 & 1 & 0.657 & 0 & 0 & 0 & - \\
\hline
\end{tabular}

Organ dysfunction* : including heart,liver, renal dysfunction, pleural effusio and peritoneal effusion

\section{Comparison of Adverse Fetal Outcomes among Groups}

Adverse fetal outcomes are shown in Table 3. The number of adverse fetal outcomes is different in five groups (non-PE group: $13 / 54$ vs. PE group: $124 / 275, p=0.004$; group A: $16 / 53$ vs. group B: $19 / 64$ vs. group C: $36 / 53, p<0.001$ ).

Between non-PE and PE group, PE group had higher frequencies in premature $(p=0.010), \operatorname{FGA}(p=0.024)$, light for date infant $(p=0.014)$, and oligohydramnios $(p=0.012)$. In another three subgroups, only the rate of premature $(p=0.009)$, stillbirth $(p=0.001)$ and birth weight $(p$ $=0.001)$ have significant difference. Though it seems that group $C$ had more fetal complications, the incidence not increased by 24 -hour proteinuria degree.

\section{Table3:Adverse fetal outcomes}




\begin{tabular}{|c|c|c|c|c|c|c|c|}
\hline & \multirow[t]{2}{*}{ Non-PE } & \multirow[t]{2}{*}{ PE } & \multirow{2}{*}{$\begin{array}{l}p \\
\text { value }\end{array}$} & \multicolumn{3}{|l|}{ subgroups } & \multirow{2}{*}{$\begin{array}{l}p \\
\text { value }\end{array}$} \\
\hline & & & & A & B & C & \\
\hline Number & 54 & 275 & - & 53 & 64 & 53 & - \\
\hline $\begin{array}{l}\text { Total adverse } \\
\text { fetal outcomes }\end{array}$ & 13 & 124 & 0.004 & 16 & 19 & 36 & $<0.001$ \\
\hline $\begin{array}{l}\text { Premature } \\
\text { \<37week) }\end{array}$ & 3 & 56 & 0.010 & 15 & 7 & 18 & 0.009 \\
\hline FGR & 0 & 24 & 0.024 & 3 & 5 & 6 & 0.563 \\
\hline $\begin{array}{l}\text { Low birth } \\
\text { weight* }\end{array}$ & 0 & 28 & 0.014 & 6 & 4 & 4 & 0.596 \\
\hline Oligohydramnios & 0 & 29 & 0.012 & 6 & 8 & 3 & 0.437 \\
\hline Stillbirth & 1 & 16 & 0.229 & 0 & 3 & 9 & 0.002 \\
\hline Birth weight, g & $3157.46 \pm 494.72$ & $2878.16 \pm 709.86$ & 0.008 & $2872.02 \pm 559.15$ & $3010.25 \pm 607.36$ & $2444.76 \pm 871.95$ & 0.001 \\
\hline
\end{tabular}

Low birth weight $\star \varangle$ including light for date infant and premature low birth weight infants; FGR: Fetal Growth Restriction $₫ A$ : 24-hour urinary protein $<0.3 \mathrm{~g} ; \mathrm{B}: 24$-hour urinary protein $0.3 \sim 2 \mathrm{~g} ; \mathrm{C}: 24$-hour urinary protein $\geqq 2 \mathrm{~g}$

\section{Correlation Analysis of Risk Factors of Adverse Pregnancy Outcome}

In order to further determine the impact of proteinuria and other factors on pregnancy outcomes in patients with PE, a correlation test and binary logistics regression analysis were used in the multivariate analysis to compare parameters with $P<0.05$ in the univariate analysis, as shown in Table 4 and Table 5. Albumin, uric acid, creatinine, gestational weeks and proteinuria were associated with maternal complications in preeclampsia pregnant women (albumin: $r=-0.405, p<0.001$; uric acid: $r=0.304, p<0.001$; creatinine $r=0.235, p=0.003$; gestational weeks: $r=-0.236, p=0.003$; proteinuria: $r=0.239, p=0.002$ ). The factors highly related to the adverse fetal outcome were gestational weeks $(r=-0.463, p<0.001)$ and proteinuria $(r=0.336, p<0.001)$. Incorporate meaningful indicators of correlation analysis into multivariate logistic analysis, the predictive indicators with statistically significant differences obtained by multivariate regression analysis are albumin, urine acid. Proteinuria is negatively correlated with gestational week $(r=-0.309, p<0.001)$ and albumin $(r=-0.360, p<0.001)$, suggesting that 24-hour proteinuria may have an indirect predictive value for adverse outcomes.

Table4.Correlation test between various diagnostic indicators and adverse outcomes

\begin{tabular}{|lllllllll|}
\hline & & $\begin{array}{l}\text { Gestational } \\
\text { weeks }\end{array}$ & $\begin{array}{l}\text { 24-hour urine protein } \\
(\mathrm{mg} / 24 \mathrm{~h})\end{array}$ & SBP & DBP & Albumin & $\begin{array}{l}\text { Urine } \\
\text { acid }\end{array}$ & Creatinine \\
\hline$r$ & $\begin{array}{l}\text { Maternal } \\
\text { complications }\end{array}$ & -0.236 & 0.239 & 0.057 & 0.026 & -0.405 & 0.304 & 0.235 \\
\hline$p$ & 0.003 & 0.002 & 0.256 & 0.381 & $<0.001$ & $<0.001$ & 0.003 \\
\hline$r$ & Fetal complications & -0.463 & 0.345 & 0.244 & 0.328 & -0.296 & 0.228 & 0.145 \\
\hline$p$ & & $<0.001$ & $<0.001$ & 0.002 & $<0.001$ & $<0.001$ & 0.004 & 0.048 \\
\hline$r$ & 24h proteinuria & -0.309 & 1 & 0.226 & 0.290 & -0.360 & 0.197 & 0.166 \\
\hline$p$ & $<$ & $<0.001$ & - & 0.004 & $<0.001$ & $<0.001$ & 0.020 & 0.052 \\
\hline
\end{tabular}

Table5:Multivariate logistic model predicting adverse outcomes of preeclampsia 


\begin{tabular}{|c|c|c|c|c|c|}
\hline & $B$ & Standard deviation & WALD & Sig. & OR (95Cl\%) \\
\hline \multicolumn{6}{|c|}{ Adverse maternal outcomes } \\
\hline albumin & -0.157 & .052 & 9.163 & .002 & $.855(0.773-0.946)$ \\
\hline Urine acid & 0.004 & .002 & 3.978 & .046 & $1.004(1.000-1.009)$ \\
\hline proteinuria & 0.000 & .000 & 0.178 & .673 & $1.000(1.000-1.000)$ \\
\hline creatinine & -0.002 & .009 & 0.040 & .841 & $0.998(0.980-1.016)$ \\
\hline Gestational week & -0.079 & .056 & 1.956 & .162 & $0.924(0.828-1.032)$ \\
\hline constant & 5.871 & 2.955 & 3.946 & .047 & 354.479 \\
\hline \multicolumn{6}{|c|}{ Adverse fetal outcomes } \\
\hline Nulliparaty & -0.163 & .452 & 0.129 & 0.719 & $0.850(0.351-2.061)$ \\
\hline Gestational week & -0.111 & .066 & 2.854 & .091 & $.895(0.787-1.018)$ \\
\hline proteinuria & 0.000 & .000 & 0.395 & .530 & $1.000(1.000-1.000)$ \\
\hline SBP & 0.013 & .019 & 0.513 & .474 & $1.013(0.977-1.051)$ \\
\hline DBP & -0.041 & .027 & 2.337 & .126 & $.960(0.911-1.012)$ \\
\hline albumin & -0.162 & .054 & 9.120 & .003 & $.851(0.766-0.945)$ \\
\hline Urine acid & 0.005 & .002 & 4.544 & .033 & $1.005(1.000-1.009)$ \\
\hline creatinine & -0.002 & .010 & 0.041 & .839 & 0.998(0.979-1.017) \\
\hline ALT & -0.001 & .003 & 0.135 & .714 & $0.999(0.992-1.006)$ \\
\hline constant & 9.087 & 4.186 & 4.713 & .030 & 8842.119 \\
\hline
\end{tabular}

DBP: Diastolic Blood Pressure; SBP: Systolic Blood Pressure『 ALT, Alanine aminotransferase; AST, Aspartate aminotransferase.

\section{The Best 24-hour Urine Protein Cutoff Value in Preeclampsia to Determine Adverse Outcomes}

In studying the relationship between 24-hour proteinuria and adverse outcomes in women with preeclampsia, we found there were differences in the incidence of hypoalbuminemia, organ dysfunction, premature delivery and stillbirth in different level of 24-hour proteinuria, so we explore the potential diagnostic value of 24-hour proteinuria to predict adverse outcomes. Table 6 and Figure 1(1a to 1d) show the best 24-hour proteinuria cutoff values based on ROC curves. The cutoff value to determine adverse outcomes was 872.09 $\mathrm{mg} / 24 \mathrm{~h}$, its corresponding area under the ROC curve (AUC) was $0.698(p<0.001)$ and odds ratios $(95 \%$ confidence interval, $\mathrm{Cl}$ ) was 5.03 (2.60-9.74). The cutoff value to determine hypoproteinemia was $1935 \mathrm{mg} / 24 \mathrm{~h}$, the AUC was $0.740(p<0.001)$ and ORs ( $95 \%$ Cls) was 6.7 (2.6-17.4). The cutoff value to determine stillbirth, premature and intrauterine distress were $3965.0 \mathrm{mg} / 24 \mathrm{~h}, 984.75 \mathrm{mg} / 24 \mathrm{~h}$ and 1503.85 $\mathrm{mg} / 24 \mathrm{~h}$, those AUC were $0.816,0.618$ and $0.745(p<0.001, p=0.034$ and $p=0.003$, respectively) and ORs ( $95 \% \mathrm{Cls})$ were 12.46 (3.4644.88), 2.48 (1.15-5.37) and 10.02 (2.14-46.80), respectively. Although univariate analysis showed that there was a difference in the incidence of organ dysfunction among urinary protein subgroups, the cutoff value obtained by ROC curve was not significant.

Table6:Relationship between 24hour urine protein cutoff value based on ROC curve and pregnant outcomes. 


\begin{tabular}{|c|c|c|c|c|c|c|c|c|c|c|}
\hline & $\begin{array}{l}\text { 24hour urine protein cutoff } \\
\text { value } ₫ \mathrm{mg} / 24 \mathrm{~h} \rrbracket\end{array}$ & $\mathrm{Se}$ & Sp & OR & $\begin{array}{l}95 \% \\
\mathrm{Cl} \text { of } \\
\text { OR }\end{array}$ & $\begin{array}{l}\text { Youden } \\
\text { index }\end{array}$ & AUC & $\begin{array}{l}\text { Standa- } \\
\text { rd error }\end{array}$ & $P$ & $95 \% \mathrm{Cl}$ \\
\hline $\begin{array}{l}\text { Adverse } \\
\text { outcomes }\end{array}$ & 872.09 & 0.63 & 0.76 & 5.03 & $\begin{array}{l}2.60- \\
9.74\end{array}$ & 0.386 & 0.698 & 0.041 & $<0.001$ & $\begin{array}{l}0.618 \\
0.777\end{array}$ \\
\hline hypoproteinemia & 1935 & 0.72 & 0.74 & 6.7 & $\begin{array}{l}2.6- \\
17.4\end{array}$ & 0.46 & 0.740 & 0.057 & $<0.001$ & $\begin{array}{l}0.629 \\
0.851\end{array}$ \\
\hline Stillbirth & 3965.0 & 0.67 & 0.86 & 12.46 & $\begin{array}{l}3.46- \\
44.88\end{array}$ & 0.529 & 0.816 & 0.048 & $<0.001$ & $\begin{array}{l}0.722 \\
0.910\end{array}$ \\
\hline Premature & 984.75 & 0.62 & 0.60 & 2.48 & $\begin{array}{l}1.15- \\
5.37\end{array}$ & 0.224 & 0.618 & 0.054 & 0.034 & $\begin{array}{l}0.511 \\
0.724\end{array}$ \\
\hline $\begin{array}{l}\text { Intrauterine } \\
\text { distress }\end{array}$ & 1503.85 & 0.85 & 0.66 & 10.02 & $\begin{array}{l}2.14- \\
46.80\end{array}$ & 0.492 & 0.745 & 0.055 & 0.003 & $\begin{array}{l}0.638 \\
0.853\end{array}$ \\
\hline
\end{tabular}

Se, Sensitivity; Sp, Speciality; OR, Odds Ratio; Cl: Confidence Interval; AUC: Area Under Curve.

\section{Discussion}

Previous studies have shown that the quantity of 24-hour urinary protein was positively correlated with the severity of PE and the occurrence of adverse pregnancy outcome $[5,9,10]$. Therefore, proteinuria has been regarded as one of the necessary indicators for clinical diagnosis of PE [6]. However, in recent years, the necessity of urinary protein in the diagnosis of PE has been controversial. In a 2010 study [11], the researchers showed that PE patients with proteinuria had higher blood pressure and cesarean section rate than PE patients without proteinuria, but urinary protein was not a predictor of adverse pregnancy outcome. The ACOG (2013) adjusted urinary protein from a necessary index to an additional index, and deleted 24-hour urinary protein $\geq 5 \mathrm{~g}$ from the diagnostic criteria of severe PE since only a minimal relationship existed between proteinuria and adverse pregnancy outcomes [12]. Chinese guideline for diagnosis and treatment of hypertensive disorder complicating pregnancy (2015 Edition) also pointed out that proteinuria was not a decisive factor in the diagnosis of PE, but played an important role in evaluating the prognosis of PE [13]. In 2018, The International Society for the Study of Hypertension in Pregnancy (ISSHP) defined presence of proteinuria is not necessary to diagnose preeclampsia [14]. At the same time, some scientists still hold the opinion that proteinuira is closely related to adverse pregnancy outcome in patients with preeclampsia, but few studies proved the relationship between the degree of proteinuria and a specific perinatal / neonatal outcome in women with preeclampsia.

In present study, the rate of cesarean section in PE group was significantly higher than that in non-PE group. It seems like that preeclampsia requires early termination of pregnancy but the cervix is immature, or severe condition requires immediate termination of pregnancy. Besides, our results showed the incidence of adverse outcome in PE group was higher than that in non-PE group, including hypoalbuminemia, oligohydramnios, organ dysfunction, retinal disease, premature delivery, FGR, low birth weight infants, this result is consistent with Tomimatsu T`s [15], suggesting that PE is one of the factors affecting pregnancy outcome. PE is a kind of pregnancy induced hypertension with systemic vascular disorder (vascular endothelial dysfunction). It is characterized by hypertension related to proteinuria. The basic pathophysiological lesion is systemic arteriolar spasm. This disease affects almost every organ system and leads to complications related to preeclampsia [16]. When renal arterioles were affected, renal blood perfusion decreased, glomerular filtration rate decreased, basement membrane cells were damaged, vascular endothelial cells were destroyed, resulting in increased vascular permeability, massive protein lose and albuminuria [16]. A large amount of albuminuria makes pregnant women prone to hypoproteinemia and organ dysfunction. Retinal arteriole spasm can easily lead to retinal detachment. In addition, pregnant women are in a state of hypercoagulability during pregnancy, and the pathogenesis of vascular endothelial cell injury in patients with preeclampsia further leads to microvascular thrombosis, and oligohydramnios in patients with preeclampsia may be caused by placental microthrombosis [16, 17]. From the pathological characteristics of preeclampsia, proteinuria may be a window to predict the pregnancy outcome of patients with preeclampsia.

In this study, non-PE patients were limited to undiagnosed preeclampsia and without proteinuria, while not all PE patients had proteinuria according to the 2015 diagnostic guidelines, and there were differences in basic conditions and a variety of biochemical indexes between the two groups, which could not show that urinary protein had an impact on the pregnancy outcome of preeclampsia pregnant women. Because of this potential limitation, we performed subgroup analysis and correlation analysis on patients with preeclampsia who underwent 24-hour urinary protein detection to further explore the relationship between urinary protein and pregnancy outcome. We Loading [MathJax]/jax/output/CommonHTML/jax.js cording to the level of urinary protein in order to determine 24-hour urinary protein. There were 
differences in the incidence of induced labor, hypoalbuminemia, organ dysfunction, premature delivery and stillbirth in pregnant women with 24-hour proteinuria. Contrary to Newmans[18], SérgioHofmeisterMart $\in$ s-Costas [19] findings, their study showed that excessive proteinuria did not mean a more serious outcome, and the increased proteinuria had nothing to do with the risk of adverse outcomes, in present study we found the increase of urinary protein could add the rate of adverse outcome of preeclampsia. Moreover, with the increase of the degree of 24-hour urinary protein, the incidence of induced labor, hypoproteinemia and stillbirth increased, this results demonstrate that urinary protein may be one of the factors of adverse pregnancy outcome in patients with preeclampsia. This result leads to similar conclusion to Kumaris[20] and Chans [21].

A number of studies have shown that the main factor affecting perinatal outcome is gestational age $(18,22)$. As was reported in our results, the gestational weeks of patients with urinary protein $>2 \mathrm{~g} / 24 \mathrm{~h}$ were significantly shorter than those of $<0.3 \mathrm{~g} / 24 \mathrm{~h}$ and $0.3 \sim 2 \mathrm{~g} / 24 \mathrm{~h}$, and the incidence of preterm delivery was higher, gestational week is negatively correlated with $24 \mathrm{~h}$ urine protein. Nonetheless, our results are not sufficient to show that the shortened gestational week is caused by the influence of urine protein, it is still unknown whether this increase in premature birth rate is the result of doctors' choice or whether it is caused by the disease process itself. We used correlation analysis to explore the influencing factors of adverse pregnancy outcome in patients with preeclampsia. The results showed that 24-hour urinary protein, serum albumin,creatinine, uric acid and gestational age were all related to adverse pregnancy outcome. Binary logistic regression analysis results showed the predictive indicators with statistically significant differences were albumin, urine acid. The accuracy of the model predicting the adverse maternal outcome and adverse fetal outcome were $72.6 \%, 68.2 \%$, respectively. In our study, we also found $24 \mathrm{~h}$ urinary protein was negatively correlated with albumin. In short, we cannot deny the role of $24 \mathrm{~h}$ urinary protein in predicting adverse outcomes in patients with preeclampsia.

For decades, there were many studies on the diagnostic value of urinary protein in preeclampsia, but few studies have used ROC curves to prove the relationship between the degree of urinary protein and a specific perinatal / neonatal outcome in women with preeclampsia. In 2020, Mamoru Morikawa et al (23) first demonstrated the relationship between the severity of the Protein:creatinine (P/C) ratio at delivery and perinatal / neonatal outcomes among women with preeclampsia based on a ROC curve, the best P/C ratio cutoff values in preeclampsia to determine early preterm birth (EPB) and maternal central serous chorioretinopathy (CSC) were 4.1 and 4.8 , respectively. The results indicated that the best cutoff value of the $\mathrm{P} / \mathrm{C}$ ratio at delivery for worsened perinatal outcomes in women with preeclampsia was 4.8. In present study, we used the ROC curve to analyze the relationship between 24hour urine protein and adverse outcomes of patients with preeclampsia, and obtained the corresponding cutoff value. The cutoff value to determine adverse outcomes, hypoproteinemia, stillbirth, premature and intrauterine distresswas were $872.09 \mathrm{mg} / 24 \mathrm{~h}, 1935 \mathrm{mg} / 24 \mathrm{~h}, 3965.0 \mathrm{mg} / 24 \mathrm{~h}, 984.75 \mathrm{mg} / 24 \mathrm{~h}$ and 1503.85 $\mathrm{mg} / 24 \mathrm{~h}$, respectively. Obviously, the cutoff values of $24 \mathrm{hour}$ urine protein varies from different adverse outcomes, this may be one of the reasons for the controversy in the application of urine protein in preeclampsia. These cutoff values were limited in clinical application, but it is undeniable that proteinuria has been once again confirmed to be associated with adverse outcomes, this also suggests that doctors still need to be vigilant about proteinuria in the treatment of patients with preeclampsia.

\section{Conclusions}

In summary, the increase of 24-hour urinary protein may lead to an increase in the incidence of adverse outcomes in women with preeclampsia. We suggest that urinary protein should be retained as one of the prognostic indicators for patients with preeclampsia. However,the pregnancy outcome of patients with preeclampsia is affected by many factors, so the monitoring of urinary protein combined with the consideration of gestational weeks, complications and other laboratory indicators may have a more accurate prediction of adverse pregnancy outcomes.

\section{Abbreviations}

ALT: Alanine Aminotransferase

AST: Aspartate aminotransferase

AUC: Area Under Curve

Cl: Confidence Interval

DBP: Diastolic Blood Pressure

DIC: Disseminated Intravascular Coagulation

Loading [MathJax]/jax/output/CommonHTML/jax.js 
EPB: Early Preterm Birth

FGR: Fetal Growth Restriction

ORs: Odds Ratio

P/C Ratio: Protein Creatinine Ratio

PE: Pre-eclampsia

ROC: The Receiver Operating Characteristic curve

SBP: Systolic Blood Pressure

\section{Declarations}

\section{Ethics approval and consent to participate}

No patient consent was required for this retrospective cohort study.

\section{Consent for publication}

All authors have reviewed the manuscript and consent for publication.

\section{Availability of data and materials}

Not applicable

\section{Competing interests}

The authors declare that they have no competing interests.

\section{Funding}

This work was supported by The project of Tutorial System of Medical Undergraduate in Lab Teaching \& Management Center in Chongqing Medical University (Grant NO. LTMCMTS202001) and Chongqing Research Institute Performance Incentive Guidance Special Project (Grant No. cstc2018jxjl130026).

\section{Authors' contributions}

All authors contributed to the article. TL, TQ, WL and XL contributed to the study conception and designed the study. TL, TQ and WL collected and summarized all epidemiological and clinical data. XL and HH provided summaries of previous research studies. TL, TQ, WL, $\mathrm{KL}$ contributed to the statistical analysis. $\mathrm{TL}, \mathrm{KL}$ and $\mathrm{LC}$ revised the final manuscript. All authors read and approved of the final manuscript.

\section{Acknowledgments}

Not applicable.

\section{References}

1. Lin S, Leonard D, Co MA, Mukhopadhyay D, Giri B, Perge L, et al. Pre-eclampsia has an adverse impact on maternal and fetal health. Transl Res. 2015;165(4):449-463.

2. Fishel Bartal M, Lindheimer MD, Sibai BM. Proteinuria during pregnancy: definition, pathophysiology, methodology, and clinical significance. Am J Obstet Gynecol. 2020; doi: 10.1016/j.ajog.2020.08.108.

3. Jing Cai, Tao Wang, Mingzhe Li, Xiaoling Cheng and Yan Zhang. Isolated proteinuria in Chinese pregnant women with pre-eclampsia: Results of retrospective observational study. Biomedical Research. 2015; 28 .11: 5162-5166

4. Ekiz A, Kaya B, Polat I, Avci ME, Ozkose B, Kicik Caliskan R, Yildirim G. The outcome of pregnancy with new onset proteinuria without hypertension: retrospective observational study. J Matern Fetal Neonatal Med. 2016;29(11):1765-9. 
5. Julio, Mateus, Roger, Newman, Baha M, Sibai, et al. Massive Urinary Protein Excretion Associated with Greater Neonatal Risk in Preeclampsia. AJP Rep. 2017; doi:10.1055/s-0037-1601866.

6. Pregnancy Hypertension Group of Obstetrics and Gynecology Branch of Chinese Medical Association $₫$ Guidelines for the Diagnosis and Treatment of Hypertensive Disorders Complicating Pregnancy (2012). Chinese Journal of Obstetrics and Gynecology. 2012; doi:10.3760/cma.j.issn.0529-567x.2012.06.018.

7. Shinar S, Asher-Landsberg J, Schwartz A, Ram-Weiner M, Kupferminc MJ, Many A. Isolated proteinuria is a risk factor for preeclampsia: a retrospective analysis of the maternal and neonatal outcomes in women presenting with isolated gestational proteinuria. J Perinatol. 2016;36(1):25-29.

8. Bouzari Z, Javadiankutenai M, Darzi A, Barat S. Does proteinura in preeclampsia have enough value to predict pregnancy outcome?. Clin Exp Obstet Gynecol. 2014;41(2):163-168.

9. Rezk M, Abo-Elnasr M, Al Halaby A, Zahran A, Badr H. Maternal and fetal outcome in women with gestational hypertension in comparison to gestational proteinuria: A 3-year observational study. Hypertens Pregnancy. 2016; 35(2):181-188.

10. Kate, Bramham, Carlos E, Poli-de-Figueiredo, Paul, et al. Association of proteinuria threshold in pre-eclampsia with maternal and perinatal outcomes: a nested case control cohort of high risk women. PLoS One. 2013; doi:10.1371/journal.pone.0076083.

11. Thornton, C E, Makris A, Ogle RF, Tooher JM, Hennessy A. Role of proteinuria in defining pre-eclampsia: Clinical outcomes for women and babies. Clinical and Experimental Pharmacology and Physiology. 2010;37: 466-470.

12. American College of Obstetricians and Gynecologists; Task Force on Hypertension in Pregnancy. Hypertension in pregnancy. Report of the American College of Obstetricians and Gynecologists' Task Force on Hypertension in Pregnancy. Obstet Gynecol. 2013;122(5):11221131.

13. Pregnancy Hypertension Group of Obstetrics and Gynecology Branch of Chinese Medical Association $\nabla$ Guidelines for the Diagnosis and Treatment of Hypertensive Disorders Complicating Pregnancy (2015)凶Chinese Journal of Obstetrics and Gynecology. 2016; 019(003):161-169.

14. Brown, Mark A, Magee, Laura A, Kenny, Louise C, et al. Hypertensive Disorders of Pregnancy: ISSHP Classification, Diagnosis, and Management Recommendations for International Practice. Hypertension. 2018;72(1):24-43.

15. Tomimatsu T, Mimura K, Matsuzaki S, Endo M, Kumasawa K, Kimura T. Preeclampsia: Maternal Systemic Vascular Disorder Caused by Generalized Endothelial Dysfunction Due to Placental Antiangiogenic Factors. Int J Mol Sci. (2019) 20(17):4246. doi:10.3390/ijms20174246

16. Xu Zhuang, Jianhua Lin. Correlation between 24-hour Urine Protein and Adverse Pregnancy Outcome in Patients with Preeclampsia.Chinese Journal of Obstetrics and Gynecology. (2014) 7. doi:10.3760/cma.j.issn.0529-567x.2014.07.013

17. Zi Yang. Etiology and Management of Oligohydramnios. Journal of Practical Obstetrics and Gynecology. 2008;24(004):197-199.

18. Newman MG, Robichaux AG, Stedman CM, Jaekle RK, Fontenot MT, Dotson T, et al. Perinatal outcomes in preeclampsia that is complicated by massive proteinuria. Am J Obstet Gynecol. 2003;188(1):264-268.

19. Martins-Costa, Sérgio Hofmeister, Vettorazzi J, Valério, Edimárlei, Maurmman C, Benevides G, Hemessath M, et al. Protein creatinine ratio in random urine sample of hypertensive pregnant women: maternal and perinatal outcomes. Hypertens Pregnancy. 2011;30(3):331-337.

20. Kumari A, Chakrawarty A, Singh A, Singh R. Maternofoetal complications and their association with proteinuria in a tertiary care hospital of a developing country. J Pregnancy. 2014;2014:431837.

21. Chan P, Brown M, Simpson JM, Davis G. Proteinuria in pre-eclampsia: how much matters?. BJOG. 2005;112(3):280-285.

22. Schiff E, Friedman SA, Kao L, Sibai BM. The importance of urinary protein excretion during conservative management of severe preeclampsia. Am J Obstet Gynecol. 1996;175(5):1313-1316.

23. Morikawa M, Mayama M, Saito Y, Nakagawa K, Umazume T, Chiba K, et al. Severe proteinuria as a parameter of worse perinatal/neonatal outcomes in women with preeclampsia. Pregnancy Hypertens. 2020;19:119-126.

\section{Figures}

Loading [MathJax]/jax/output/CommonHTML/jax.js 


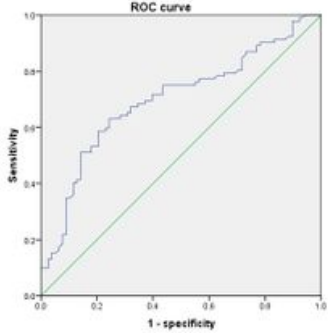

A

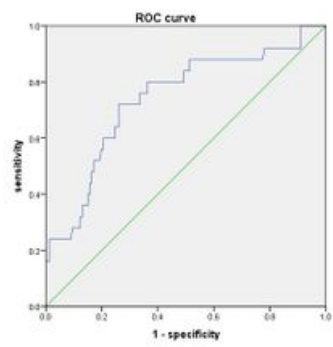

B

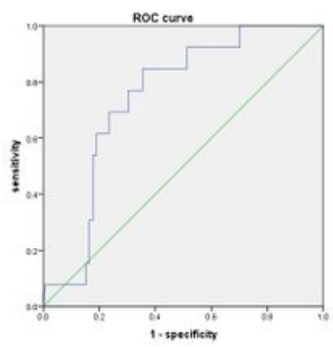

C

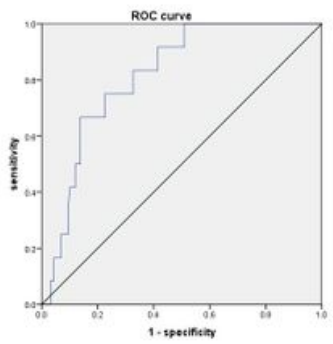

D

Figure 1

a: 24-hour urine collection cutoff value to determine adverse outcomes b: 24-hour urine collection cutoff value to determine hypoproteinemia c: 24-hour urine collection cutoff value to determine intrauterine distress $d$. 24-hour urine collection cutoff value to determine stillbirth 